\title{
Intermediaries and destination reputations: Explaining flows of skilled migration
}

\begin{abstract}
Governments have increasingly commercialised their migration services, which has fuelled a mushrooming migration industry creating a ripe context for the central role of migration intermediaries. It is therefore timely to explore the new actors responsible for shaping contemporary flows of skilled migration. Drawing on the work of existing studies and a wide variety of secondary data, we argue that the range of intermediaries who have emerged as a result of the commercialisation process, have been poorly understood in the skilled migration and migration industries literatures. Discussion of these actors sheds important theoretical light on how intermediaries, destination reputations and skilled migration flows intersect. Accordingly, we outline six propositions that identify the interconnected relationship between migration intermediaries, reputation and skilled migration flows.
\end{abstract}

\section{Keywords}

Skilled migration flows; Intermediaries; Destination reputations; Social networks; Migration industries

\section{Introduction}

The commercialisation of migration services has led to a proliferation of non-state actors and there has been a subsequent growth of literature on the so called 'migration industries' (Gammeltoft-Hansen and Nyberg Sørensen, 2013, Findlay et al., 2013; Cranston, 2014, 2016; Cranston et al., in press). At the same time, there has been a lack of discussion of skilled migration flows, despite the fact that they represent an important talent pool for countries (Harvey, 2014; Silvanto et al., 2015). The migration literature identifies the factors that shape migration decisions, by examining different scales of analysis (e.g. immigration policy at the macro level; network contacts at the meso level and individual decisions at the micro scale). Social network theory has been an important framework to understand how these networks connect individuals at the micro level to immigration policies at the macro level and to job opportunities and integration experiences at the meso level (Lindquist et al., 2010). However, surprisingly there has been little consideration in the migration industries literature of social networks or the interconnecting factors at the macro, meso and micro levels which influence skilled migration flows.

To date, there has been limited research on how intermediaries shape the flows of skilled migrants, reinforcing and reproducing the commercial interests within the migration industries. Skilled migrant intermediaries are actors operating at the intersection between skilled migrants and the destination or origin country (Groutsis et al., 2015; van den Broek et al., 2016). They are similar to what the international labour organisation (ILO) refer to as a 'triangular employment relationship' when the intermediary (rather than the employer) engages directly with the migrant (ILO, 2005). These intermediaries are also referred to as 'brokers', 'middlemen' and 'autonomous enterprises', and represent an essential part of the migration industries in the global labour market. There has also been little analysis of how intermediaries service skilled migrants (cf. Groutsis et al., 2015; van den Broek et 
al., 2016) and how the migration industry impacts on migration patterns and networks (GammeltoftHansen and Nyberg Sørensen, 2013; Spaan and Van Naerssen, this volume). Given changes to both the scale of skilled migration and the nature of intermediaries, it is timely to analyse how intermediaries impact on skilled migration flows. One of the contributions of this paper is to highlight the variety of intermediaries beyond those who are already well-known in the skilled migration industries literature such as migration, recruitment and global mobility firms (Findlay et al., 2013; Cranston, 2016; McCollum and Findlay, in press) to provide a broader understanding of how these disparate actors are impacting on skilled migration flows.

A second important contribution of the paper is to show that different forms of destination reputations, which are often addressed in isolation such as country reputations, city reputations and organisational reputations, influence skilled migration flows in different and salient ways. While there have been many attempts to define reputation (Fombrun, 1996, 2012; Walker, 2010), this research develops the important work of Fombrun (2012) and Walker (2010) to define reputation as the collective positive or negative assessment of destinations among skilled migrants. In addition to our narrow understanding of intermediaries, there is arguably even less understanding of how reputation impacts on skilled migration flows. This paper provides clarity around how destination reputations impact on skilled migration flows.

Given the gaps in our understanding from the migration industries literature on social networks, intermediaries, skilled migration flows and reputation, the paper focuses on addressing this neglect while also connecting these different strands of literature.

\section{Skilled migration flows and social networks}

There has been a surge of cross-disciplinary interest in skilled migrants in the last decade (Harvey, 2011; van Riemsdijk, 2014). The focus on skilled migration in the literature has been matched by a growth of coverage in the media, government and supranational policies and reports as well as in the business press (Boxell, 2010; Chaloff, and Lemaître, 2009; The Economist, 2010; PwC, 2010). There are many definitions of skilled migrant and it is not our intention to problematise existing definitions (see Boucher and Cerna, 2014; Findlay and Cranston, 2015). Instead, we follow Andresen et al. (2014: 2307), and use the term skilled migration broadly to encompass a wide spectrum of workers, including intra selfinitiated expatriates (e.g. individuals looking for global opportunities through their existing organisational employers), inter self-initiated expatriates (e.g. dependent workers such as foreign recruits and independent workers such as entrepreneurs), assigned expatriates (e.g. traditional organisational expatriates) and drawn expatriates (e.g. top global executives approached by organisations).

The literature on skilled migration has argued that flows of skilled migration are driven by considerations at the macro, meso and micro level. At the macro-(country) level, factors such as the political, economic and legal climate may determine whether people stay in their home country or move to a destination country (Massey et al., 1993; Regets, 2001). Immigration policy and the allocation of particular visas, for example, will impact upon the volume of skilled migrants. At the meso-level, there is a wealth of research on how various forms of individual and organisational networks affect migration decisions (Vertovec, 2002; Harvey, 2011). For instance, migrant networks have historically influenced the migration flows of skilled migrants. At the micro-level, there is extensive research on individual 
migration decisions, including but not limited to the importance of economic, professional, political and environmental factors (Borjas, 1999; Hardill and Macdonald, 2000). Skilled migrants, for example, may move based on their predictions of where they can maximise their return in the labour market or where they can increase their quality of life. What is absent, however, is an explanation of flows of migration which cross-sects the macro, meso and micro-level (de Haas, 2010) in what Xiang (2012: 68) describes as the "complex structure of the middle ground". The literature on migrant social networks has responded by adopting a multi-level analysis to bridge macro and micro level approaches to migration (Lindquist et al., 2010), which has been somewhat absent from the migration industries literature.

Although the migration industries literature highlights new actors in the migration process (GammeltoftHansen and Nyberg Sørensen, 2013), there has been little exploration of new social networks which emerge as a result of these nascent actors, despite an extensive literature on social networks and migration flows (Curran and Rivero-Fuentes, 2003). Massey et al. (1993: 448) argue that migrant networks are the social ties that connect potential and former migrants as well as non-migrants in sending and destination countries through family, friendship, ethnic origin and workplace ties. Social networks are important for facilitating flows of skilled migration because the contacts migrants have with different actors provide them with valuable information about their likely experiences of moving to another country (de Haas, 2010) and therefore reduce the cost burden of migration. They are also the means by which workers in sending countries find work in destination countries through connections to various forms of intermediaries (Pittman, 2016), which highlights the links between social networks and commercially driven migration intermediaries. Ryan (2015) shows the complexity surrounding skilled Irish migrants forming trusted networks in Britain, which significantly impacts upon their experiences of mobility. The above literature highlights that social networks, if available, are important for helping skilled migrants to both migrate and integrate into destination countries.

\section{Skilled migrant intermediaries}

Turning attention to intermediaries and how they shape migration flows shifts the starting point of migration decision making from social networks to intermediary relations (Lindquist et al., 2012; Groutsis et al., 2015; van den Broek et al., 2016). While there is an established literature on how social networks impact the flow of skilled migrants, we know little about new forms of social networks that have emerged between skilled migrants and various intermediaries. From the perspective of skilled migrants, there has been an absence of detailed labour market information around the practicalities and realities of immigrating to destination countries. This information vacuum stymies a developed understanding of new market opportunities for intermediaries and what the reputational implications of that may be for migration destinations.

Despite a growing literature on skilled migration and labour market intermediaries (Forde and MacKenzie, 2010; Lindquist et al., 2012), there has been an absence of discussion of what we refer to as 'skilled migrant intermediaries'. These intermediaries use social networks to connect skilled migrants in sending countries, provide them with information and services related to labour market opportunities, and mediate between migrants, client organisations and sending and destination countries at critical stages of the migration process (Lindquist et al., 2012; Xiang, 2012). There is a 'grapevine of intermediaries' (Krissman, 2005: 6) and a 'complex articulation of individuals, associations, and organizations' (Goss and Lindquist, 1995: 319), which has intensified the increasingly dependent 
relationship between migrants and intermediaries (Groutsis et al., 2016). Consequently, there is a need for 'middle-level theory' and 'meso-scale understanding' (Findlay and Li, 1998: 682, 683), particularly in the context of the migration industries, so that we can better understand this complex web of relationships (Xiang, 2012) and their impact on flows of skilled migration.

Given the changing nature of international migration, which is marked by a rise in skilled mobility and a demand-driven approach to attracting such migrants (Saxenian, 2006; Harvey, 2011), it is important to understand who these different skilled migrant intermediaries are and how they affect skilled migration flows through social networks, particularly given the proliferation of new forms of online and social media. Despite some emerging literature on reputation and skilled migration (Harvey and Groutsis, 2015), there is a scarcity of understanding around how intermediaries influence and are influenced by destination reputation among skilled migrants, and the implication this has on skilled migration flows. This represents a further body of literature and provides important insights for the migration industries which has given less focus to skilled migration flows.

\section{Insert Table 1 about here}

\section{Reputation}

While absent from the migration industries literature, there is an extensive literature on reputation that has been applied in the context of organisations. Fombrun and Shanley (1990) argue that the reputation of organisations will impact upon the job and career choices of potential employees. For example, Glückler (2007) argues that management consulting firms may win new client work to further build their reputations, which has implications for attracting both clients and employees. Aula and Harmaakorpi (2008) established that firms are more attracted to locating in regions which are strongly networked and which hold high levels of social capital. Building on this literature is the intersection of migration and mobility. Harvey and Groutsis (2015), for example, have argued that skilled migrants are both influenced by origin and destination country reputations when making migration decisions, but are also producers of the reputation of origin and destination countries, based on their direct experiences, which shapes their own perceptions as well as those of other skilled workers. This is important because it provides a new theoretical lens to understand skilled migration flows to destination countries.

We build on the reputation literature and ask how flows of skilled migration are shaped by destination reputations. We deliberately use the phrase 'destination reputations' rather than 'destination country reputations' because we recognise that the country may not be the only or the most salient unit of analysis in the context of reputation among skilled migrants. Destination reputation is arguably important in the context of understanding flows of skilled migration because how countries, cities and/or organisations are perceived will determine mobility decisions among skilled migrants. Skilled migrants often have limited experience and/or information about moving to destinations and in such instances they use reputation as a proxy for judging their likely experience of moving to a destination. 
As such, social networks, skilled migrant intermediaries and reputation should be important components of existing theories of skilled migration flows, and yet these themes are not wellunderstood or connected in the migration industries literature. This leads to a series of propositions that relate to the following research question:

How do migration intermediaries, destination reputations and skilled migration flows interact, reinforce and reproduce the migration industry?

Drawing-upon a wide range of examples, we outline six propositions, which explore the two-way interaction between intermediaries, destination reputations among skilled migrants and depictions of skilled migration flows to destinations (see Figure 1 ). We believe that this provides a more holistic understanding of skilled migration flows and represents a significant contribution to both the skilled migration and the migration industries literatures.

\section{Insert Figure 1 about here}

\section{Proposition 1: The activities of skilled migrant intermediaries impact on the reputation of destinations among skilled migrants.}

An emerging body of labour market research highlights the centrality of intermediaries such as recruitment agencies across a range of countries and economic sectors (Samaluk, 2016). While valuable for understanding the nature of different labour market sectors, by overlooking how these intermediaries may shape the reputation of destinations among skilled migrants (Coe et al., 2010; Findlay et al., 2013), we miss important implications on the talent pipeline of destinations. A sector where one type of intermediary: recruitment agents, has become commonplace for placing skilled migrants in work, is in healthcare where employers need to quickly fill shortages with skilled migrants (Connell and Stilwell, 2006). While the state has significant influence here, as detailed further on in our discussion, private sector employers are increasingly playing a significant role in the recruitment of skilled labour through employer-sponsored programs. In Canada, for example, the Federal Skilled Worker Program assesses skilled migrants on the basis of their education, work experience and knowledge of English and French. Canadian employers can significantly improve the likelihood of a potential skilled migrant having their application approved through making them a job offer in a skilled occupation (Citizenship and Immigration Canada, 2012). These developments have underscored the proliferation of individual private recruitment firms, temporary staffing and migration agents (Connell and Stilwell, 2006; Coe et al., 2009; Cangiano and Walsh, 2014; McCollum and Findlay, in press) and the internationalisation of labour markets as employers struggle to source talent from local and national labour pools. Such an emphasis on the demand side of skilled (migrant) labour, which is apparent throughout OECD member nations (OECD, 2008), highlights the economic incentive for recruitment agents to act as conduits for both domestic employers and skilled migrants abroad.

The transactional relationship between intermediaries and skilled migrants, is an outcome of macrolevel transitions from the 'hollowing out' of government to network governance models (Groutsis et al., 2015). As a consequence, intermediaries are strategically placed to shape the reputation of destination 
countries among skilled migrants, which historically would have been managed more directly by national governments. The challenge is if promises are made by intermediaries, but not fulfilled at the point of migration and employment then this will disengage skilled migrants. For instance, more than '1.3 million college-educated immigrants are unemployed or working in unskilled jobs such as dishwashers, security guards, and taxi drivers-representing one of every five highly skilled immigrants in the US labor force' (Batalova and Fix, 2008: 1). If intermediaries are channelling skilled migrants into destination countries where they subsequently cannot find work commensurate with their skills and training then this will have a negative impact on the reputation of destinations (and intermediaries) among skilled migrants.

One type of recruitment agency that typically enables the mobility of skilled workers at the high end of the labour market is executive search firms (Boyle et al., 1996) or 'elite labour market intermediaries' (Faulconbridge et al., 2008). Examples of these firms include Egon Zehnder, Korn Ferry and Spencer Stuart, who operate on a global scale, connecting applicants who hold and/or are looking to move into senior management positions. Typically, the search for such highly skilled workers operates across international borders and frequently leads to the global mobility of workers, particularly in areas where certain leadership and technical skills are not readily available in the destination country. These types of intermediaries rely on very close social networks between the client organisation and the executive search firm as well as between the potential candidates and the executive search firms. Because many high level executive appointments receive significant media coverage (e.g. Mark Carney, the Governor of the Bank of England moving from Canada to the UK), the success or failure of such appointments, which can be considerably costly for clients of executive search firms, will heighten the reputational benefits or deficits for destinations due to the professional and personal networks of skilled migrants.

\section{Proposition 2: The reputation of destinations among skilled migrants impact on the activities of skilled migrant intermediaries.}

Counter-intuitively, government departments also act as intermediaries for skilled migrants because their policies and communication impact upon migration decisions and behaviour. However, marketisation of government has "fragmented service delivery, multiplied networks and diversified membership of those networks" (Rhodes, 2007: 1248), at a time when migration is a highly emotive public discourse. Public concerns around immigration, for example, was at the centre of the outcome of the UK's referendum vote in June of 2016, which has major repercussions for skilled migration flows to and from the UK within the European Union. Governments in the destination country also implement policies that determine how many and what types of skilled migrants are able to enter a country, and under what conditions. They collate skills shortages lists, actively market professional vacancies and hold expo events abroad to target workers with particular skills. In addition, they set the conditions for particular types of relationships between migrants, employers and labour markets (Rodriguez, 2009). This has significant repercussions for employers who are looking to employ skilled migrants and for skilled migrants, many of who are looking to move for work purposes. Sporton's (2013) research on Eastern European migration finds how international recruitment agents are able to identify demand for workers in particular under-performing local labour markets, while Bludau's (2011) research finds that recruitment firms in the Czech Republic provide a supply of skilled migrant nurses, who are seeking employment abroad. The destination reputations among skilled migrants impacts on the demand for talent from employers and the potential supply of talent from skilled migrants interested in moving, both of which influence the activities of intermediaries. 
The Prime Minister of Singapore, Lee Hsien Loong has made many public statements and supported the recruitment of professionals and business workers through government policy as part of a strategy of growing the city-state's knowledge-based economy (Ho, 2011). These policies create a positive reputation among potential skilled migrants around the value the Singaporean government places on their human capital. This has meant that there are a variety of intermediaries, including but not limited to migration and recruitment agents, who enable skilled migration flows into Singapore. This is in stark contrast with rhetoric in the U.S. where there have been discussions of a reduction in the country's $\mathrm{H}-1 \mathrm{~B}$ visa allocation, culminating in high-profile business leaders such as Microsoft's Chairman Bill Gates (Broache, 2008) and News Corporation's Executive Chairman Rupert Murdoch (Murdoch, 2014) warning of the damage that this could cause to the country's competitiveness because skilled migrants would be put off applying for visas and less would be admitted each year. Here, restrictive immigration policies around the country's skilled $\mathrm{H}-1 \mathrm{~B}$ visa will reduce the capacity of different intermediaries such as migration agents to operate. This argument has knock-on effects for other kinds of skilled workers because restrictive and bureaucratic visa requirements impact on the flow of tourists, business workers and temporary migrants (The Economist, 2016).

\section{Proposition 3: The activities of skilled migrant intermediaries impact on skilled migration flows.}

A number of organisations in the destination country attempt to adopt a direct approach to recruiting skilled migrants (Pittman, 2016). Multinational corporations with offices in overseas locations are particularly well placed to do this because they can transfer employees to other locations as assigned expatriates (Salt, 1992). While some organisations are successful at convincing skilled migrants directly of the benefits of living and working in a destination, the engagement of particular intermediaries is not even across different migrant groups. Khoo et al. (2005), for instance, found that $83 \%$ of Korean skilled migrants in Australia preferred to use a migration agent, compared to only $23 \%$ of German skilled migrants. They found that Asian migrants in particular used agents because they felt that they might attain 'a high rate of approval' which facilitates their ability to gain access to the Australian labour market (Khoo et al., 2005: 30). Havergal (2015) reports that there has been an unprecedented growth of agents commissioned by universities in the UK to recruit non-EU students, implying that these intermediaries are important for influencing the flow of skilled migrants into the UK.

Organisations that are sourcing executive and specialist roles often do not have the internal expertise and capacity to source this talent and therefore frequently utilise the services of executive search firms (Faulconbridge et al., 2009), as discussed above. Many medium and large organisations are outsourcing recruitment and selection work to other intermediaries such as recruitment and migration agents for efficiency and competitive purposes so that they can focus their resources on their core services. Importantly, this is not simply a labour market intermediary argument of organisations outsourcing services to a specialist service provider. They are also relying on these intermediaries to convince potential talent, many of whom are skilled migrants, of the positive benefits of living and working in a particular country. Hence, they play a valuable role in shaping the destination reputation for skilled migrants. 


\section{Proposition 4: Skilled migration flows impact on the activities of skilled migrant intermediaries.}

Approximately half of overseas-qualified nurses in the UK gain posts through specialist migration agents, with the remainder recruited directly through individual hospitals, which have an international profile and points of overseas contacts (Hardill and Macdonald, 2000). At the time of Hardill and MacDonald's (2000) study, a fee of $£ 2,000$ was paid for an agent's service and typically employees would be offered a one-year contract. This use of migration agents in the healthcare sector is a direct response to high market demand for skilled migrants and the knowledge and image of such opportunities among this group in different parts of the world.

Migration agents play an important intermediation role for overseas students looking to enter the higher education market (Collins, 2012). Although international students are not always defined under the category of skilled migrants, they are in the process of becoming skilled migrants through their education and training. A report by the Observatory on Borderless Higher Education (2014) found that $32 \%$ of first year international students at 48 universities in the three largest destination countries (the US, UK and Australia) used a migration or recruitment agent: a 10\% increase in the last five years. As such, intermediaries are shaping skilled migration flows in powerful ways, channelling students into particular tertiary institutions in certain countries (see Beech this volume).

\section{Proposition 5: The reputation of destinations among skilled migrants impact on skilled migration flows.}

There has been a surge of reputational rankings in the last decade. One of the conceptual challenges of these rankings in the context of skilled migration flows is that there is a disconnect between different forms of reputation such as corporate reputations, country reputations and city reputations. Yet, we suggest below that they all impact on skilled migration flows in different and salient ways. Many rankings have focused on the reputations of organisations across different sectors such as Fortune's Most Admired Companies (Fortune, 2015), or have focused on one sector in particular such as the Times Higher Education World University Rankings (2015). Notwithstanding the considerable methodological limitations of measuring reputation, these formal and informal reputation benchmarks enable reputable firms to accrue significant benefits from high rankings, including the ability to attract and retain talent (Fombrun, 1996). Hence, we suggest that reputation is important for attracting skilled migrants, who are an important part of an organisation's talent pool. Samsung, for example, has successfully sourced high quality software engineers to move from India to South Korea because of the company's high reputation (Harvey and Groutsis, 2015). Saxenian (2006) has documented a similar phenomenon in the US with large volumes of skilled migrants in the ICT sector moving to Silicon Valley because of the presence of nearby elite universities (e.g. Stanford and UC Berkeley) and IT firms (e.g. Apple and Google). Samaluk (2016) has found that workers are attracted to move to particular places (often misguidedly) because their reputations may grant them particular social capital or economic returns. In short, organisational reputation has a strong influence on the mobility of talent, including but not limited to skilled migrants.

Reputation is also important at a national and regional level and there are a growing number of high profile and widely distributed survey rankings, which also influence skilled migration. HSBC's Expat Explorer Survey (2014), for instance, commissioned YouGov to survey over 9,000 expatriates in more 
than 100 countries, asking questions on economics, work and social experiences, and raising children. The InterNations (2014) annual survey targets thousands of expatriates and skilled migrants, and it highlights the best and worst places to live, with questions focusing on quality of life, ease of settling in, working abroad, family life (if applicable), personal finance and general satisfaction. The experiences of skilled migrants living abroad can vary markedly not only between but also within countries, and there are a number of influential surveys of global cities. The Economist's (2014) annual liveability survey presents safety and environmental factors in 140 global cities. Similarly, Mercer's (2015) quality of living survey looks at a range of factors, including climate, disease, sanitation standards, ease of communication, the political and social environment, and crime.

The above reputational rankings (corporate, country and city) are important because they reach a wide, skilled and influential audience, providing skilled migrants with information about moving to potential destinations. Yet, they have not been recognised in the skilled migration or migration industries literatures as having an impact upon skilled migration decisions. Importantly, these ranking agents will portray positive, negative or sometimes ambivalent representations of different places, which will influence skilled migration flows because skilled migrants will typically consider the pros and cons of living in multiple destinations. The implication is there are multiple forms of reputation, all of which act in tandem rather than in isolation when skilled migrants make migration decisions. These operate together because in reality skilled migrants will use all the information available to them, which entails aggregating these reputations, rather than evaluating them individually. This does not mean that all reputations are treated equally because skilled migrants will weigh factors differently depending on the degree of importance to them.

\section{Proposition 6: Skilled migration flows impact on destination reputations among skilled migrants.}

There is an extensive literature on the effect that migrant networks have on shaping decisions to migrate to a particular destination country (Massey et al., 1993; Goss and Lindquist, 1995). Chacko (2007) found that many Indian professionals moved to the US because of the positive stories they had heard from skilled migrants who had successfully moved. Surprisingly, there has been relatively little understanding of how different experiences of moving to destination countries may impact upon the destination reputation among skilled migrants. Much of the literature on skilled migrants has overlooked the impact of media, online content and social media in shaping destination reputation for skilled migration flows. Montgomery (2008) is one of the few exceptions in her discussion of Indian and Taiwanese engineers using their social ties with fellow alumni by e-mail to share their perceptions of destination country experiences. With increasing advancements in IT and the prevalence with which people are engaging with different forms of media, it is not surprising that there has been rapid growth in informal migrant intermediaries such as online expatriate forums and social media groups. American Expats in the UK, for example, is an online forum for American expatriates planning to move to the UK, or for those who have already moved to the country, to discuss a range of topics with other members such as migration and relocation issues, finding work, health care, schooling as well as participating in sports and social activities (American Expats in the UK, 2011). Such online resources provide a range of migration information from skilled migrants or from skilled migration experts, which shape the destination reputations among potential skilled migrants. However, there has been a dearth of research 
or media coverage of how information shared through such channels can explicitly and implicitly shape destination reputations among skilled migrants.

To date, there has been very little research conducted on how information on skilled migration emerges and is shared on online forums or different media, and in particular social media (e.g. SnapChat, Facebook, Twitter and LinkedIn), which in turn impacts on the destination reputations among skilled migrants. This is a major oversight because we know in social and business contexts, such forums can play a valuable role in communicating reputations (Jøsang et al., 2007). So it would be reasonable to predict that such online forums where migratory experiences are shared play an important role in shaping destination reputations among skilled migrants.

\section{Discussion}

Based on existing studies and a wide range of secondary data, we have formulated six propositions that seek to better understand flows of skilled migration today. Returning to our research question, we argue that there are important interaction effects between skilled migrant intermediaries, destination reputations among skilled migrants, and skilled migration flows. This is an important contribution to the migration industries literature which has hitherto given less attention to skilled migration flows and social networks which cut across different scales of analysis, or to the reputational effects of these interactions. We also argue that there is a growing group of intermediaries who are influencing the migration flows of skilled migrants. The implication is that national governments may lose both control and responsibility of their reputation among skilled migrants, particularly if such intermediaries are invisible (Xiang, 2012). This is salient given our multidimensional argument of reputation which incorporates not one but multiple forms of reputation and cross sects at the macro, meso and micro levels.

The literature on social networks has an important role to play in these propositions because social networks influence each relationship. In particular, important information is exchanged between skilled migrants and intermediaries, which influences destination reputations and ultimately flows of skilled migrants. For example, the social ties between intermediaries and skilled migrants will impact upon the destination reputations among skilled migrants through information exchanged between both groups (proposition 1). Such networks create and shape destination reputations among skilled migrants. However, we recognise that social networks are neither the same, nor operate in a uniform way in relation to the six propositions (see also Curran and Rivero-Fuentes, 2003).

There is only partial evidence from the migration industries literature on the different types of skilled migrant intermediaries and one of the contributions of this paper is to highlight the broad ranging nature of intermediaries beyond the well-known influence of migration and recruitment agents. There is also little analysis of how intermediaries shape the destination reputations among skilled migrants, or how the reputations of destinations among skilled migrants impact on the activities of intermediaries (proposition 2). This is another important contribution of this paper because current theories of skilled migration have not adequately captured the importance of intermediaries despite their prevalence in the skilled migration labour market, nor have they captured the impact of social networks between intermediaries and skilled migrants. This is at the very time that the outsourcing of migration and its commercialisation has become more prevalent, meaning that traditional network ties with government 
have become fragmented (Rhodes, 2007), attracting new intermediaries into the field (Lindquist et al., 2012; Gammeltoft-Hansen and Nyberg Sørensen, 2013; Groutsis et al., 2015; van den Broek et al., 2016). It is these visible and invisible actors and the interactions that they are forging that are reinforcing and reproducing the migration industry. It is timely to understand the different social ties that exist between intermediaries and skilled migrants, not least because it impacts upon destination reputations among skilled migrants.

Figure 1 shows the complex nature in which networks intersect with skilled migrant intermediaries and the destination reputations among skilled migrants. We suggest that there is no clear cause/effect binary between these dimensions, but instead they are bound by mutual but by no means equal interdependencies. The behaviour of skilled migrant intermediaries will impact upon the destination reputation and skilled migration flows. This is a process facilitated by the information that is transferred from intermediaries to potential skilled migrants (proposition 3). At the same time, the perceptions of skilled migration flows will affect the demand for intermediaries and therefore their subsequent activities (proposition 4).

Social networks are critical because information is disseminated through information channels, which can be online (e.g. mass media, popular media, social media or gaming), or offline (e.g. through face-toface interaction). Significantly, because new intermediaries and technologies have emerged in the last decade, many new offline and online social networks between skilled migrants and intermediaries have arisen which have yet to be explored in the migration industries literature. The destination reputations among skilled migrants are shared through social networks, which will impact upon the skilled migration flows to destination countries (proposition 5). Intermediaries can shape destination reputations among skilled migrants in a positive way and therefore constitute 'reputation builders' for countries, or in a negative way as 'reputation damagers' (Harvey and Groutsis, 2015b). This represents both an opportunity and a risk for destination countries and therefore cannot be ignored because of the direct impact of reputation on flows of skilled migration. At the same time, prior experiences of moving to destination countries also shape migration flows, with migrants following each other along the "beaten track' (de Haas, 2010: 1589). This will impact on destination reputations among skilled migrants through experiences of skilled migration flows to destinations (proposition 6).

\section{Conclusions and Future research}

This paper has argued that the relationship between skilled migrant intermediaries and destination reputations among skilled is central for understanding today's flows of skilled migrants. We have highlighted that intermediaries are common and more wide-ranging than the literature has acknowledged and comprise a key part of the actors in the migration industry, which to date has provided less analysis of skilled migration flows and new forms of social networks. According to Cangiano and Walsh (2014), employers in the UK and Ireland are using intermediaries because of the excessive burden of keeping up-to-date with immigration regulation, but it is less clear how aware various organisations and migrants are of the extent to which intermediaries are, or should be, regulated. Arguably increased regulation of various forms of intermediaries will help to reduce misconduct towards skilled migrants and also ensure that governments and organisations are more aware of how these actors shape the flows of skilled migrants (see Cranston this volume for an example). A failure to acknowledge and analyse the function of intermediaries will entrench 
misunderstanding of a major and disparate stakeholder group who are increasingly shaping skilled migration flows today.

At present, we do not know whether the experience for skilled migrants has changed in light of these new forms of intermediaries, either positively or negatively. Hence, we encourage scholars to pursue more fine-grained research into the different intermediaries that exist, including those discussed above as well as others (e.g. NGOs and trade unions). We need to understand the activities of these various intermediaries and ascertain what the reputational outcomes are. This will affect not only future flows of skilled migrants, but also future levels of business partnerships and investments, which are often harnessed through the social networks of skilled migrants (Saxenian, 2006).

We have also argued that destination reputations among skilled migrants plays a major role in explaining flows of skilled migrants. In particular, the destination reputations among skilled migrants will influence and be influenced by skilled migration flows to destinations by third parties and a multitude of intermediaries. One aspect, which could be further developed, is that of reputation contagion, which we define as the means by which one form of reputation impacts upon another form of reputation, either positively or negatively. If a group of skilled migrants, for instance, have encountered negative experiences with migration agents then this will not only impact upon the reputation of migration agents (intermediaries) at a local level, but also the reputation of the organisation (e.g. corporate reputation). The logic for this is their experiences of work in the destination have also been tarnished because of their negative experiences of moving to another country (Harvey and Groutsis, 2015). This 'reputational spillover' effect (Glückler, 2007) between the intermediary, organisation and country, can be a positive or a negative force and can be long term and enduring. However, we know very little about the interplay of various forms of reputation and what implications they have for flows of skilled migrants. This is theoretically important because we need a holistic understanding of the impact of reputation, and practically important because there are arguably various actors who influence the flows of skilled migrants who interest groups such as NGOs, trade unions and the media are starting to question. In addition, given that the perceptions of migrants are strongly shaped by their early experiences and can often be filled with unrealistic expectations (Bhattacharya and Schoppelrey, 2004), destination countries should pay particular attention to the experiences of early arrivals, which is difficult when many migration services are outsourced to third parties amid varying levels of regulation and monitoring. This is a similar challenge that organisations face in other contexts when their reputation now depends not only on their own activities, but also on the activities of others (Tate et al., 2010; The Economist, 2014; Schapendonk, this issue). Arguably this makes them more vulnerable to the 'reputation commons' when all organisations suffer in a given sector when the actions of one organisation negatively impact upon the reputation of the industry as a whole (Barnett and King, 2008).

This paper provides an important contribution to the migration industries literature by highlighting that a range of intermediaries and reputation are important for theorising flows of skilled migration today, particularly through different forms of social networks. We also explain that intermediaries, reputation and skilled migration flows do not operate in isolation, but interact with one another, which provides a more holistic understanding of skilled migration flows. We encourage scholars to deepen the empirical evidence of the relationship between intermediaries, reputation and skilled migration flows, and in 
particular explore how social networks enable (or disable) these relationships. Now is a timely moment to expand our research and analysis of these new actors and relationships, particularly given their relative invisibility in the migration industries literature.

\section{References}

Andresen, M., Bergdolt, F., Margenfeld, J. and Dickmann, M. (2014). Addressing international mobility confusion-developing definitions and differentiations for self-initiated and assigned expatriates as well as migrants. The International Journal of Human Resource Management, 25, 16, 2295-2318.

American Expats in the UK (2011), 'Bringing the American Community together around the UK'. http://www.americanexpats.co.uk/forum/index.php

Aula, P. and Harmaakorpi, V. (2008), 'An innovative milieu-a view on regional reputation building: case study of the Lahti urban region', Regional Studies, 42, 4, 523-538.

Barnett, M.L. and King, A.A. (2008), 'Good fences make good neighbors: a longitudinal analysis of an industry self-regulatory institution', Academy of Management Journal, 51, 6, 1150-1170.

Batalova, J. and Fix, M. (2008), Uneven Progress: The Employment Pathways of Skilled Immigrants in the United States. With Peter A. Creticos. Washington, DC, Migration Policy Institute. www.migrationpolicy.org/pubs/BrainWasteOct08.pdf

Bhattacharya, G. and Schoppelrey, S.L. (2004), 'Preimmigration Beliefs of Life Success, Postimmigration Experiences, and Acculturative Stress: South Asian Immigrants in the United States', Journal of Immigrant Health, 6, 2, 83-92.

Bludau, H. (2011), 'Producing transnational nurses: agency and subjectivity in global health care labor migration recruitment practices', Anthropology of East Europe Review, 29, 1, 94-108.

Borjas, G.J. (1999), 'The economic analysis of immigration', Handbook of Labor Economics, 3, 1, 16971760.

Boucher, A. and Cerna, L. (2014). Current policy trends in skilled immigration policy. International Migration, 52, 3, 21-25.

Boxell, J. (2010), 'Skilled migrants face tougher rules'. http://www.ft.com/intl/cms/s/0/6c8c0754-e20111df-a064-00144feabdc0.html\#axzz1YNdQmFxQ

Boyle, M., Findlay, A.M., Lelievre, E. and Paddison, R. (1996), 'World Cities and the Limits to Global Control: A Case Study of Executive Search Firms in Europe's Leading Cities', International Journal of Urban and Regional Research, 20, 498-517.

Broache, A. (2008), 'Bill Gates to Congress: Let us hire more foreigners', CNET, http://www.cnet.com/news/bill-gates-to-congress-let-us-hire-more-foreigners/

Buchan, J., Jobanputra, R. and Gough, P. (2005), 'Should I stay or should I go?', Nursing Standard, 19, 36, 14-16. 
Cangiano, A. and Walsh, K. (2014). 'Recruitment processes and immigration regulations: the disjointed pathways to employing migrant carers in ageing societies', Work, Employment and Society, 28, 3, 372389.

Castles, S. (2010), 'Understanding global migration: a social transformation perspective', Journal of Ethnic and Migration Studies, 36, 10, 1565-1586.

Chacko, E. (2007), 'From brain drain to brain gain: Reverse migration to Bangalore and Hyderabad, India's globalizing high tech cities', GeoJournal, 68, 131-140.

Chaloff, J. and Lemaître, G. (2009), 'Managing Highly Skilled Labour Migration: A Comparative Analysis of Migration Policies and Challenges in OECD Countries'. OECD Social, Employment and Migration Working Papers, No. 79, OECD Publishing. http://dx.doi.org/10.1787/225505346577

Chambers E.G., Foulon, M. Handfield-Jones, H. Hankin, S.M. and Michaels, E.G. (1998), 'The war for talent', McKinsey Quarterly, 1, 3, 44-57.

Coe, N.M., Johns, J. and Ward, K. (2009), 'Agents of casualization? The temporary staffing industry and labour market restructuring in Australia', Journal of Economic Geography, 9, 1, 55-84.

Coe, N.M., Jones, K. and Ward, K. (2010). 'The Business of Temporary Staffing: A Developing Research Agenda.' Geography Compass, 4, 8, 1055-1068.

Collins, F.L. (2012), 'Organizing student mobility: education agents and student migration to New Zealand', Pacific Affairs, 85, 1, 137-160.

Connell, J. and Stillwell, B. (2006), 'Merchants of medical care: Recruiting agencies in the global health care chain', in Merchant of Labour, ed. C. Kuptsch, Geneva, Switzerland: International Labour Organization (Institute for Labour Studies), 239-253.

Cranston, S., (2014), 'Reflections on Doing the Expat Show: Performing the Global Mobility Industry', Environment and Planning A, 46, 5, 1124-1138.

Cranston, S. (2016), 'Producing migrant encounter: Learning to be a British expatriate in Singapore through the Global Mobility Industry', Environment and Planning D: Society and Space 34, 4, 655-671.

Cranston, S. Schapendonk, J. and Spaan, E. (in press). New Directions in Exploring the Migration Industries: Introduction to Special Issue. Journal of Ethnic and Migration Studies.

Curran, S.R. and Rivero-Fuentes, E. (2003), 'Engendering migrant networks: the case of Mexican migration', Demography, 40, 2, 289-307.

de Haas, H. (2010), 'The Internal Dynamics of Migration Processes: A Theoretical Inquiry', Journal of Ethnic and Migration Studies, 36, 10, 1587-1617.

(The) Economist (2010), 'Skilled immigration. Green-card blues'.

http://www.economist.com/node/17366155 
(The) Economist (2014), The best places to live. Url:

http://www.economist.com/blogs/graphicdetail/2014/08/daily-chart-13

(The) Economist (2016), Travel visas. A strange sort of welcome. Url:

http://www.economist.com/news/business/21684791-governments-are-deterring-business-travellersand-tourists-cumbersome-visa-requirements

Faulconbridge, J.R., Hall S.J.E. and Beaverstock J.V. (2008), 'New insights into the internationalization of producer services: organizational strategies and spatial economies for global headhunting firms', Environment and Planning A, 40, 1, 210-234.

Faulconbridge, J.R., Beaverstock, J.V., Hall, S. and Hewitson, A. (2009), 'The 'war for talent': the gatekeeper role of executive search firms in elite labour markets', Geoforum, 40, 5, 800-808.

Findlay, A.M. and Cranston, S. (2015). What's in a research agenda? An evaluation of research developments in the arena of skilled international migration. International Development Planning Review, 37(1), 17-31.

Findlay, A.M., McCollum, D., Shubin, S., Apsite, E. and Krisjane, Z. (2013), 'The role of recruitment agencies in imagining and producing the 'good' migrant', Social and Cultural Geography, 14, 2, 145-67.

Findlay, A.M. and Li, F.L.N. (1998), 'A Migration Channels Approach to the Study of Professionals Moving to and from Hong Kong', International Migration Review, 32, 3, 682-703.

McCollum, D. and Findlay, A.M. (in press). Oiling the wheels? Flexible labour markets and the migration industry. Journal of Ethnic and Migration Studies.

Fombrun, C.J. and Shanley, M. (1990). What's in a name? Reputation building and corporate strategy. Academy of Management Journal, 33(2): 233-258.

Fombrun, C.J. (1996), Reputation. Realizing Value from the Corporate Image, Boston, Massachusetts: Harvard Business School Press.

Fombrun, C.J. (2012), 'The building blocks of corporate reputation: Definitions, antecedents, consequences', In Barnett, M.L. and Pollock, T.G. (Eds.) The Oxford Handbook of Corporate Reputation, Oxford University Press, Oxford, 94-113.

Forde, C. (2008), "'You know we are not an Employment Agency": Manpower, Government, and the Development of the Temporary Help Industry in Britain', Enterprise \& Society, 9, 2, 337-365.

Forde, C. and MacKenzie, R. (2010), 'The Ethical Agendas of Employment Agencies Towards Migrant Workers in the UK; Deciphering the Codes', Journal of Business Ethics, 97, 1, 31-41.

Fortune (2015), 'World's Most Admired Companies 2015', Url: http://fortune.com/worlds-mostadmired-companies/apple-1/

Gammeltoft-Hansen, T., and Nyberg Sørensen, N. (2013), The Migration Industry and the Commercialization of International Migration. Abingdon, Oxon, Routledge. 
Glückler, J. (2007), 'Geography of reputation: the city as the locus of business opportunity', Regional Studies, 41, 7, 949-961.

Goss, J and Lindquist, B (1995), 'Conceptualizing international labor migration: A structuration perspective', The International Migration Review, 29, 2, 317-351.

Groutsis, van den Broek, D. and Harvey, W.S. (2015), 'Transformations in Network Governance: The Case of Migration Intermediaries', Journal of Ethnic and Migration Studies, 41, 10, 1558-1576.

Hardill, I. and MacDonald, S. (2000), 'Skilled International Migration: The Experience of Nurses in the UK', Regional Studies, 34, 7, 681-692.

Harvey, W.S. and Groutsis, D. (2015), 'Reputation and talent mobility in the Asia Pacific', Asia Pacific Journal of Human Resource Management, 53, 1, 22-40.

Harvey, W.S. (2014), 'Winning the global talent war: A policy perspective', Journal of Chinese Human Resource Management, 5, 1, 62-74.

Harvey, W.S. (2011), 'British and Indian scientists moving to the U.S.', Work and Occupations, 38, 1, 68100.

Havergal, C. (2015), 'Agents paid an average of $£ 1,767$ per non-EU recruit' Times Higher Education. Url: https://www.timeshighereducation.co.uk/news/agents-paid-an-average-of-1767-per-non-eurecruit/2018613.article

Ho, E.L.E. (2011), “'Claiming' the diaspora: elite mobility, sending state strategies and the spatialities of citizenship", Progress in Human Geography, 35, 6, 757-772.

HSBC (2014), 'Expat Explorer Survey', Url:

https://expatexplorer.hsbc.com/survey/?HBIB dyn Ink=hme nav t4 col1 Ink 1

ILO. (2005), Global alliance against forced labour. International Labour Organisation, Geneva.

InterNations (2014), 'The Best \& Worst Places for Expats', Url: http://www.internations.org/expatinsider/2014/the-best-and-worst-places-for-expats

Jøsang, A., Ismail, R. and Boyd, C. (2007), 'A survey of trust and reputation systems for online service provision', Decision Support Systems, 43, 2, 618-644.

Kea (2010), 'Kea. New Zealand's Global Network', 'About Us'. http://www.keanewzealand.com/about-us

Khoo, S., McDonald, P. and Hugo, G (2005), 'Temporary skilled migrants in Australia: employment circumstances and migration outcomes', Australian Centre for Population Research Australian National University and University of Adelaide, Department of Immigration and Multicultural and Indigenous Affairs.

Krissman, F. (2005), 'Sin Coyote Ni Patrón: Why the "Migrant Network" Fails to Explain International Migration', International Migration Review, 39, 1, 4-44. 
Lindquist, J., Xiang, B. and Yeoh, B.S. (2012), 'Opening the black box of migration: brokers, the organization of transnational mobility and the changing political economy in Asia', Pacific Affairs, 85, 1, 7-19.

MacKenzie, R. and Forde, C. (2009), 'The rhetoric of the 'good worker' versus the realities of employers' use and the experiences of migrant workers', Work, Employment \& Society, 23(1): 142-159.

MacKenzie, R., Forde, C. and Ciupijus, Z. (2012), 'Networks of Support for New Migrant Communities: Institutional Goals versus Substantive Goals?', Urban Studies, 49(3): 631-647.

Massey, D.S. Arango, J., Hugo, G. Kouaouci, A. Pellegrino, A. and Taylor, J.E. (1993), 'Theories of International Migration: A Review and Appraisal', Population and Development Review, 19, 3, 431-466.

Mercer (2015), Newsroom. Vienna tops latest Quality of Living rankings. Url:

http://www.uk.mercer.com/content/mercer/europe/uk/en/newsroom/2015-quality-of-livingsurvey.html

Montgomery 2008 - please add

Moriarty, E., Wickham, J., Krings, T., Salamonska, J. and Bobek, A. (2011), 'Taking on almost everyone?' Migrant and employer recruitment strategies in a booming labour market', The International Journal of Human Resource Management, 23, 9, 1871-1887.

Murdoch, R. (2014), 'Immigration Reform Can't Wait', Wall Street Journal, http://online.wsj.com/articles/rupert-murdoch-immigration-reform-cant-wait-1403134311

Observatory on Borderless Higher Education (2014), 'The agent question: insights from students, universities and agents', http://www.obhe.ac.uk/documents/view details?id=953

OECD (2008), 'The Global Competition for Talent: Mobility of the Highly Skilled', http://www.oecd.org/innovation/inno/theglobalcompetitionfortalentmobilityofthehighlyskilled.htm\#ho wto

Perez, P.A. and McDonough, P.M. (2008), 'Understanding Latina and Latino College Choice. A Social Capital and Chain Migration Analysis', Journal of Hispanic Higher Education, 7, 3, 249-265.

Pittman, P. (2016), 'Alternative Approaches to the Governance of Transnational Labor Recruitment', International Migration Review, 50, 2, 269-314.

PricewaterhouseCoopers (PwC) (2010), 'Managing tomorrow's people. Talent Mobility 2020. The next generation of international assignments'. http://www.pwc.com/gx/en/managing-tomorrowspeople/future-of-work/pdf/talent-mobility-2020.pdf

Regets M.C. (2001) 'Research and Policy Issues in High-Skilled International Migration: A Perspective with Data from the United States', IZA Discussion Paper 366.

Reitz, J.G. 2005. Tapping Immigrants' Skills: New Directions for Canadian Immigration Policy in the Knowledge Economy. IRPP Choices 11(1): 1-15.

Rhodes, R. A. (2007), 'Understanding governance: Ten years on', Organization Studies, 28, 8, 1243-1264. 
Rodriguez, R. M. (2009), Migrants for Export: How the Philippine State Brokers Labor to the World, Minneapolis: University of Minnesota Press.

Ryan, L. (2015), Friendship-making: Exploring Network Formations through the Narratives of Irish Highly Qualified Migrants in Britain. Journal of Ethnic and Migration Studies, 41, 10, 1664-1683.

Salt, J. (1992), 'Migration Processes amongst the Highly Skilled in Europe," International Migration Review, 26, 484-505.

Salt, J. and Stein, J. (1997), 'Migration as a Business: The Case of Trafficking', International Migration, 35, 4, 467-494.

Samaluk, B. (2016), 'Migrant workers' engagement with labour market intermediaries in Europe: symbolic power guiding transnational exchange', Work, Employment and Society, 30, 3, 455-471.

Saxenian, A. (2006), The New Argonauts. Regional Advantage in a Global Economy, Cambridge, Massachusetts: Harvard University Press.

Silvanto, S., Ryan, J. and McNulty, Y. (2015), An empirical study of nation branding for attracting internationally mobile skilled professionals, Career Development International, 20, 3, [forthcoming].

Sporton, D. (2013), "They control my life': the role of local recruitment agencies in East European migration to the UK', Population, Space and Place, 19, 5, 443-458.

Tasker, S. and Jimenez, K (2010), 'Skills crisis risks \$150bn worth of projects'.

http://www.theaustralian.com.au/business/skills-crisis-risks-150bn-worth-of-projects/story-e6frg8zx$\underline{1225967252748}$

Tate, W.L., Ellram, L.M. and Kirchoff, J.F. (2010), 'Corporate social responsibility reports: a thematic analysis related to supply chain management', Journal of Supply Chain Management, 46, 1, 19-44.

The Times Higher Education (2015), 'World University Rankings', Url: https://www.timeshighereducation.co.uk/world-university-rankings/

van den Broek, D., Harvey, W.S. and Groutsis, D. (2016), 'Commercial Migration Intermediaries and the segmentation of skilled migrant employment', Work, Employment and Society, 30, 3, 523-534.

Van Riemsdijk, M. (2014), 'International migration and local emplacement: everyday place-making practices of skilled migrants in Oslo, Norway', Environment and Planning A, 46, 4, 963-979.

Vertovec, S. (2002), Transnational Networks and Skilled Labour Migration: Transnational Communities Programme: University of Oxford, Oxford.

Walker, K. (2010), 'A systematic review of the corporate reputation literature: Definition, measurement, and theory', Corporate Reputation Review, 12, 4, 357-387.

Xiang, B. (2012), 'Predatory Princes and Princely Peddlers: The State and International Labour Migration Intermediaries in China', Pacific Affairs, 85, 1, 47-68. 
Table 1: Examples of skilled migrant intermediaries

\begin{tabular}{|c|c|c|c|c|}
\hline Proposition & $\begin{array}{l}\text { Type of skilled } \\
\text { migrant } \\
\text { intermediary }\end{array}$ & $\begin{array}{l}\text { Financial } \\
\text { cost }\end{array}$ & Examples & Related references \\
\hline $\begin{array}{l}\text { Proposition 1: The activities of } \\
\text { skilled migrant intermediaries } \\
\text { impact upon the reputation of } \\
\text { destinations among skilled } \\
\text { migrants. }\end{array}$ & $\begin{array}{l}\text { Recruitment } \\
\text { agents }\end{array}$ & High & $\begin{array}{l}\text { Manpower Inc; } \\
\text { Employment } \\
\text { Expos; }\end{array}$ & $\begin{array}{l}\text { Boyle et al., 1996; Buchan et al., } \\
\text { 2005; Connell and Stilwell, 2006; } \\
\text { Coe et al., 2009; Findlay et al., } \\
\text { 2013; McCollum and Findlay, in } \\
\text { press }\end{array}$ \\
\hline $\begin{array}{l}\text { Proposition 2: The reputation of } \\
\text { destinations among skilled } \\
\text { migrants impact on the activities } \\
\text { of skilled migrant } \\
\text { intermediaries. }\end{array}$ & Government & Medium & $\begin{array}{l}\text { Department of } \\
\text { Health; NHS; Kea } \\
\text { New Zealand }\end{array}$ & $\begin{array}{l}\text { Goss and Lindquist, 1995; } \\
\text { Larner, 2007; Bludau, 2011; } \\
\text { Sporton, } 2013\end{array}$ \\
\hline $\begin{array}{l}\text { Proposition 3: The activities of } \\
\text { skilled migrant intermediaries } \\
\text { impact on skilled migration } \\
\text { flows. }\end{array}$ & $\begin{array}{l}\text { Executive } \\
\text { search firms }\end{array}$ & Low & $\begin{array}{l}\text { Egon Zehnder; } \\
\text { Korn Ferry; } \\
\text { Spencer Stuart }\end{array}$ & $\begin{array}{l}\text { Salt, 1992; Findlay et al., 1998; } \\
\text { Khoo et al., 2005; Tasker and } \\
\text { Jimenez, 2010; van den Broek et } \\
\text { al., } 2016\end{array}$ \\
\hline $\begin{array}{l}\text { Proposition 4: Skilled migration } \\
\text { flows impact on the activities of } \\
\text { skilled migrant intermediaries. }\end{array}$ & $\begin{array}{l}\text { Migration } \\
\text { agents }\end{array}$ & High & $\begin{array}{l}\text { Barlow \& } \\
\text { Company; } \\
\text { Offshore } \\
\text { migration agents }\end{array}$ & $\begin{array}{l}\text { Salt and Stein, 1997; Hardill and } \\
\text { Macdonald, 2000; Buchan et al., } \\
\text { 2005; Coe et al., 2010; Connell, } \\
\text { 2010; Collins, 2012; Groutsis et } \\
\text { al., 2015; Pittman, } 2016\end{array}$ \\
\hline $\begin{array}{l}\text { Proposition 5: Destination } \\
\text { reputations among skilled } \\
\text { migrants impact on skilled } \\
\text { migration flows. }\end{array}$ & $\begin{array}{l}\text { Ranking } \\
\text { agents }\end{array}$ & Low & $\begin{array}{l}\text { Mercer; The } \\
\text { Economist }\end{array}$ & $\begin{array}{l}\text { HSBC, 2014; InterNations, 2014; } \\
\text { The Economist, 2014; Harvey } \\
\text { and Groutsis, 2015; Mercer, } \\
\text { 2015; }\end{array}$ \\
\hline $\begin{array}{l}\text { Proposition 6: Skilled migration } \\
\text { flows impact on destination } \\
\text { reputations among skilled } \\
\text { migrants. }\end{array}$ & $\begin{array}{l}\text { Online and } \\
\text { offline forums } \\
\text { and media } \\
\text { sources }\end{array}$ & Low & $\begin{array}{l}\text { American Expats } \\
\text { in the UK; Forbes }\end{array}$ & $\begin{array}{l}\text { Chacko, 2007; Montgomery, } \\
\text { 2008; Moriarty et al., 2011; } \\
\text { Harvey and Groutsis, } 2015\end{array}$ \\
\hline
\end{tabular}


Figure 1: Illustration of propositions mechanised through social networks

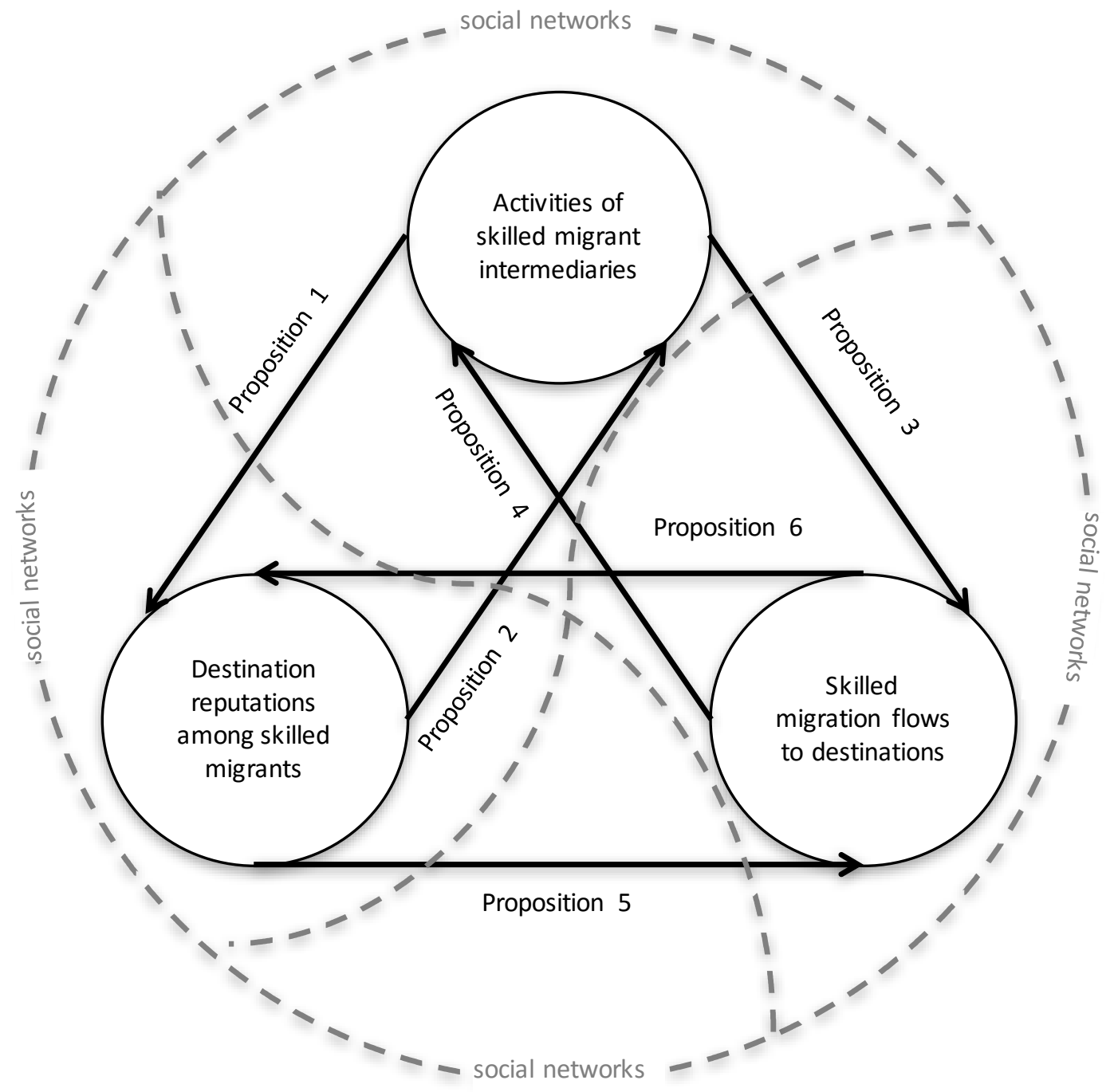

